A C G

publications

Rec. Nat. Prod. 11:6 (2017) 558-561

records of natural products

\title{
Inhibition Effects of Some Lignans on Carbonic Anhydrase, Acetylcholinesterase and Butyrylcholinesterase Enzymes
}

\author{
Leyla Polat Köse and Ilhami Gulcin*
}

\author{
Faculty of Sciences, Department of Chemistry, Atatürk University, 25240-Erzurum, Türkiye
}

(Received April 14, 2017; Revised June 05, 2017; Accepted June 12, 2017)

\begin{abstract}
Lignans are a large group of chemical compounds found in plants. They have effects on enzymes, protein synthesis, cell proliferation, angiogenesis, growth factor and cell differentiation. In this study, inhibition effects of $\alpha-(-)$-conidendrin, enterodiole, enterolactone, nordihydroguaiaretic acid, secoisolariciresinol and secoisolariciresinol diglucoside against carbonic anhydrase I and II isoenzymes (CA I, and II) and acetylcholinesterase (AChE) and butyrylcholinesterase (BChE) enzymes were investigated. The Ki values of the lignans were found to be in the ranges of 1.27-3.30 nM for CA I, 1.11-2.68 nM for CA II, $0.72-1.62 \mathrm{nM}$ for AChE, and $0.08-0.20 \mathrm{nM}$ for AChE.
\end{abstract}

Keywords: Lignans; acetylcholinesterase; butyrylcholinesterase; carbonic anhydrase. ㅇ 2017 ACG Publications. All rights reserved.

\section{Sample Source}

Lignans, possessing a 2,3-dibenzylbutane skeleton, are present in glycoside form in many plants and widely found in flaxseed, rye, cherry, berries, grain, whole wheat, vegetables, fruits and tea [1]. $\alpha$ (-)-conidendrin (1), enterodiole (2), enterolactone (3), nordihydroguaiaretic acid (4), secoisolariciresinol (5), and secoisolariciresinol diglucoside (6) are used in order to determine the inhibition effects on carbonic anhydrase, acetylcholinesterase and butyrylcholinesterase enzymes (Supporting information S1, Figure S1).

\section{Previous Studies}

Lignans have been attracting the interest of research groups for years. This is due to their phytoestrogenic properties, wide range of biological activities, including antioxidant affect, and availability in various plant species. The basic lignans found in plants are matairesinol, secoisolariciresinol, lariciresinol, pinoresinol, enterolactone and enterodiol, which show estrogenic activity in humans $[1,2]$.

Carbonic anhydrase (CA, EC 4.2.1.1) is a metalloenzyme, which catalyses reversibly hydration of $\mathrm{CO}_{2}$ and dehydration of $\mathrm{HCO}_{3}{ }^{-}$[3-5]. CA first purified from bovine erythrocytes [6,7], are found in tissues such as brain, lung, stomach, pancreas, liver, kidney, muscle tissue, and especially red blood cells $[8,9]$. It is one of the most important buffer systems in human body. CA plays a crucial role in many physiological events such as acid-base balance, ion exchange, regulation of cardiovascular

\footnotetext{
* Corresponding author: E Mail: igulcin@atauni.edu.tr 
system, and dissolve, transport and dispose of $\mathrm{CO}_{2}$ in water during respiration [10]. CAs occur in all organisms and, so far, seven different genetic families of CA are known, i.e. $\alpha-, \beta-, \gamma-, \delta-, \zeta-, \eta-$ and $\theta-$ CAs [11]. It has been determined that the average molecular mass of enzymes in mammals is around 30 $\mathrm{kDa}$ and sixteen isoenzymes have been identified so far [12]. For the CA enzymes, a wide range of isozymes is present in living systems, depending on the circumstances and requirements of the environment in which they are exist [13].

Cholinesterases are enzymes that have a wide range of distribution in both cholinergic and noncholinergic tissues, found in plasma and other body fluids [14,15]. Cholinesterases are treated in two groups, (i) acetylcholinesterase (AChE; E.C. 3.1.1.7) and (ii) butyrylcholinesterase (BChE; E.C. 3.1.1.8) $[16,17]$. AChE is found in grey matter of brain, nerve endings, intestines, lungs, spleen and erythrocytes in high concentrations. Moreover, $\mathrm{BChE}$, which is particularly common in animal kingdom, is present in serum, heart, pancreas, liver and brain [18]. Alzheimer's disease (AD), which is a type of dementia, is a common neurodegenerative disorder. This kind of dementia is defined as an insufficiency of functions on memory in brain. One of the most important causes of AD is decrease of acetylcholine in brain [19].<smiles>COc1cc(C2c3cc(OC)c(O)cc3[C@H]3COC(=O)[C@H]23)ccc1O</smiles>

1<smiles>CC(Cc1ccc(O)c(O)c1)C(C)Cc1ccc(O)c(O)c1</smiles>

4<smiles>OCC(CO)Cc1cccc(O)c1</smiles>

2<smiles>COc1cc(C[C@@H](CO)[C@H](CO)Cc2ccc(O)c(OC)c2)ccc1O</smiles>

5<smiles>O=C1OCC(Cc2cccc(O)c2)[C@H]1Cc1cccc(O)c1</smiles><smiles>COc1cc(CC(COC2OC(CO)[C@@H](O)[C@H](O)[C@H]2O)C(COC2O[C@H](CO)[C@@H](O)[C@H](O)[C@H]2O)Cc2ccc(O)c(OC)c2)ccc1O</smiles>

6

Figure 1. Chemical structures studied lignans 1-6

\section{Present Study}

CA Activity Assay: Fresh human blood erythrocytes for carbonic anhydrase I, and II isoenzymes were purified using Sepharose-4B-LTyrosine-sulfanilamide affinity chromatography technique [20]. CA activities of the isoenzymes were determined by spectrophotometric measurements at $348 \mathrm{~nm}$ [21]. A detailed information and the principal of the method were given in the supporting information (Supporting information S2, Figure S1).

Cholinergic Enzymes Assay: The effects of lignan on AChE / BChE enzymes were determined applying the method developed by Ellman et al., for which AChI and BChI were used as substrates $[8,11,22]$. For the measurement of activities of both enzymes, 5,5'-dithio-bis(2-nitro-benzoic) acid (DTNB) was used. Moreover, DTNB was also used for the measurement of absorbance of the coloured compound at $412 \mathrm{~nm}$ [23]. A detailed information and the principal of the method were given in the supporting information (Supporting information S3, Figure S2).

$\mathrm{CA}$, which also functions as a $\mathrm{pH}$ regulator and contains $\mathrm{Zn}^{2+}$ metal in the active centre, catalyses the transformation reactions of $\mathrm{CO}_{2}$ and water to $\mathrm{HCO}_{3}{ }^{-}$and $\mathrm{H}^{+}$at a very rapid rate using PNA as a substrate [24]. Additionally, CA enzymes take part in vital functions such as diversity and workability [7-10]. For the CA I isoenzyme, $\mathrm{IC}_{50}$ values were found as $9.08 \mathrm{nM}\left(\mathrm{r}^{2}: 0.9952\right)$ for $\alpha-(-)$-conidendrin, $14.07 \mathrm{nM}\left(\mathrm{r}^{2}: 0.9961\right)$ for enterodiole, $130.00 \mathrm{nM}\left(\mathrm{r}^{2}: 0.9945\right)$ for enterolactone, $17.40 \mathrm{nM}\left(\mathrm{r}^{2}: 0.9988\right)$ for nordihydroguaiaretic acid, $180.00 \mathrm{nM}\left(\mathrm{r}^{2}: 0.9994\right)$ for secoisolariciresinol and $7.74 \mathrm{nM}\left(\mathrm{r}^{2}: 0.9966\right)$ for 
secoisolariciresinol diglucoside. The positive control acetazolamide showed $\mathrm{IC}_{50}$ value of $10.58 \mathrm{nM}$ for the CA I. For the CA II isoenzyme, IC I0 $_{5}$ values were determined to be $17.47 \mathrm{nM}\left(\mathrm{r}^{2}: 0.9912\right)$ for $\alpha-(-)-$ conidendrin, $22.78 \mathrm{nM}\left(\mathrm{r}^{2}: 0.9995\right)$ for enterodiole, $26.05 \mathrm{nM}\left(\mathrm{r}^{2}: 0.9999\right)$ for enterolactone, $36.29 \mathrm{nM}$ $\left(\mathrm{r}^{2}: 0.9977\right)$ for nordihydroguaiaretic acid, $8.96 \mathrm{nM}\left(\mathrm{r}^{2}: 0.9916\right)$ for secoisolariciresinol and $48.54 \mathrm{nM}$ $\left(\mathrm{r}^{2}: 0.9992\right)$ for secoisolariciresinol diglucoside. $\mathrm{IC}_{50}$ value of the positive control acetazolamide was recorded as $36.85 \mathrm{nM}$ for the CA II. Regarding the Ki values of the tested compounds (1-6) and the positive controls (Table 1), remarkable activities against CA I, and CA II in the ranges of 1.27-3.30 nM and 1.1-2.68 nM, respectively, were obtained.

Cholinesterases are enzymes with important functions in many tissues, plasma and body fluids. They are divided into two groups, acetylcholinesterase (AChE) and butyrylcholinesterase (BChE), according to their substrate specificity and inhibitor sensitivities [23-25].

$\mathrm{IC}_{50}$ values of AChE were found as $8.75 \mathrm{nM}\left(\mathrm{r}^{2}: 0.9871\right)$ for $\alpha-(-)$-conidendrin, $9.08 \mathrm{nM}$ $\left(\mathrm{r}^{2}: 0.9808\right)$ for enterodiole, $14.02 \mathrm{nM}\left(\mathrm{r}^{2}: 0.9883\right)$ for enterolactone, $14.93 \mathrm{nM}\left(\mathrm{r}^{2}: 0.9903\right)$ for nordihydroguaiaretic acid, $8.30 \mathrm{nM}\left(\mathrm{r}^{2}: 0.9893\right)$ for secoisolariciresinol and $7.04 \mathrm{nM}\left(\mathrm{r}^{2}: 0.9857\right)$ for secoisolariciresinol diglucoside. Positive control, acetazolamide, showed $\mathrm{IC}_{50}$ value of $7.53 \mathrm{nM}$ for AChE. Regarding BChE, $\mathrm{IC}_{50}$ values were found as $0.74 \mathrm{nM}\left(\mathrm{r}^{2}: 0.9690\right)$ for $\alpha-(-)$-conidendrin, $0.66 \mathrm{nM}$ $\left(r^{2}: 0.9680\right)$ for enterodiole, $0.64 \mathrm{nM}\left(\mathrm{r}^{2}: 9884\right)$ for enterolactone, $0.78 \mathrm{nM}\left(\mathrm{r}^{2}: 0.9875\right)$ for nordihydroguaiaretic acid, $0.70 \mathrm{nM}\left(\mathrm{r}^{2}: 0.9746\right)$ for secoisolariciresinol and $0.36 \mathrm{nM}\left(\mathrm{r}^{2}: 0.9709\right)$ for secoisolariciresinol diglucoside. The standard compound, tacrine, for $\mathrm{BChE}$, displayed $\mathrm{IC}_{50}$ value of $1.24 \mathrm{nM}$. The results clearly indicated that all the lignans had effective AChE and BChE inhibition effects.

Table 1. The inhibition effects of some phenolic compounds on human carbonic anhydrase I, and II isoforms (hCA I, and II), acetylcholinesterase (AChE) and butyrylcholinesterase (BChE) enzymes.

\begin{tabular}{lcccc}
\hline \multirow{2}{*}{ Compounds } & \multicolumn{4}{c}{$\mathbf{K}_{\mathbf{i}}(\mathbf{n M})$} \\
\cline { 2 - 5 } & hCA I & hCA II & AChE & BChE \\
\hline$\alpha$-(-)-Conidendrin (1) & 2.11 & 2.03 & 1.54 & 0.15 \\
Enterodiole (2) & 2.74 & 2.68 & 1.41 & 0.14 \\
Enterolactone (3) & 3.30 & 2.63 & 1.29 & 0.16 \\
Nordihydroguaiaretic acid (4) & 2.81 & 2.56 & 1.62 & 0.17 \\
Secoisolariciresinol (5) & 2.14 & 2.52 & 1.30 & 0.20 \\
Secoisolariciresinol diglucoside (6) & 1.27 & 1.11 & 0.72 & 0.08 \\
Acetazolamide* $_{\text {Tacrine** }}$ & 4.03 & 2.90 & - & - \\
& - & - & 2.90 & 0.26 \\
\hline
\end{tabular}

* Acetazolamide was used as positive control for human carbonic anhydrase I, and II isoforms (hCA I, and II)

**Tacrine was used as positive control for acetylcholinesterase (AChE) and butyrylcholinesterase (BChE) enzymes

In conclusion, lignans, as an important group of natural compounds, showed strong inhibition effects toward the hCA I, and II, AChE and BChE enzymes. $\alpha$-(-)-conidendrin (1), enterodiole (2), enterolactone (3), nordihydroguaiaretic acid (4), secoisolariciresinol (5) and secoisolariciresinol diglucoside (6) could be considered as potential drug candidates for treatment of some diseases such as glaucoma, mountain sickness, epilepsy, gastric and duodenal ulcers, and neurological disorders.

\section{Supporting Information}

Supporting Information accompanies this paper on http://www.acgpubs.org/RNP

\section{References}

[1] I. Rowland, M. Faughan, L. Hoey and K. Wahala (2003). Bioavailability of phyto-oestrogens, Brit. J. Nutr. 89, 45-58.

[2] J.R. Cole and R.M. Wiedhopf (1978). Distribution. In: Rao CBS, editor. Chemistry of lignans. Waltair: Andhra University Press, pp. 39-64.

[3] B.F. Abdel Wahab, H.A. Mohamed and A.A. Farhat (2014). Ethyl coumarin-3-carboxylate: Synthesis and chemical properties, Org. Commun, 7(1), 1-27. 
[4] İ. Gülçin, R. Elias, A. Gepdiremen and L. Boyer (2006). Antioxidant activity of lignans from fringe tree (Chionanthus virginicus L.), Eur. Food Res. Technol. 223, 759-767.

[5] İ. Gülçin, A. Scozzafava, C.T. Supuran, H. Akıncıoğlu, Z. Koksal, F. Turkan and S.H. Alwasel (2016). The effect of caffeic acid phenethyl ester (CAPE) metabolic enzymes including acetylcholinesterase, butyrylcholinesterase, glutathione s-transferase, lactoperoxidase and carbonic anhydrase isoenzymes I, II, IX and XII, J. Enzyme Inhib. Med. Chem. 31, 1095-1101.

[6] L. Polat Kose, İ. Gülçin, H. Özdemir, A. Atasever, S.H. Alwasel and C.T. Supuran (2016). The effects of some avermectins on bovine carbonic anhydrase enzyme, J. Enzyme Inhib. Med. Chem. 31, 773-778.

[7] T. Gokcen, M. Al, M., Topal, I. Gulcin, T. Ozturk and A.C. Goren (2017). Synthesis of some natural sulphonamide derivatives as carbonic anhydrase inhibitors. Org. Commun, 10(1), 15-23.

[8] H. Genç, R. Kalin, Z. Köksal, N. Sadeghian, U.M. Kocyigit, M. Zengin, İ. Gülçin and H. Özdemir (2016). Discovery of potent carbonic anhydrase and acetylcholinesterase inhibitors: 2-aminoindan $\beta$-lactam derivatives, Int. J. Mol. Sci. 17, 1736-1749.

[9] F. Topal, I. Gulcin, A. Dastan and M. Guney (2017). Novel eugenol derivatives: potent acetylcholinesterase and carbonic anhydrase inhibitors, Int. J. Biol. Macromol. 94, 845-851.

[10] C.T. Supuran (2013). Carbonic anhydrases: from biomedical applications of the inhibitors and activators to biotechnological use for $\mathrm{CO}_{2}$ capture, J. Enzyme Inhib. Med. Chem. 28, 229-230.

[11] A. Scozzafava, P. Kalın, C.T. Supuran, İ. Gülçin and S.H. Alwasel (2015). The impact of hydroquinone on acetylcholine esterase and certain human carbonic anhydrase isoenzymes (hCA I, II, IX, and XII), J. Enzyme Inhib. Med. Chem. 30, 941-946.

[12] J.B. Feldstein and D.N. Silverman (1984). Purification and characterization of carbonic anhydrase from the saliva of the rat, J. Biol. Chem. 259, 5447-5453.

[13] M. Bozdag, F. Carta, D. Vullo, A. Akdemir, S. Isik, C. Lanzi, A. Scozzafava, E. Masini and C.T. Supuran (2015). Synthesis of a new series of dithiocarbamates with effective human carbonic anhydrase inhibitory activity and antiglaucoma action, Bioorg. Med. Chem. 23, 2368-2376.

[14 I.B. Wilson and D. Nachmansohn (1954). In Ion Transport Across Membranes, Acedemic Press Inc., p35, New York.

[15] T. Önkol, M. Gökçe, I. Orhan and F. Kaynak (2013). Design, synthesis and evaluation of some novel 3(2H)pyridazinone-2-yl acetohydrazides as acetylcholinesterase and butyrylcholnesterase inhibitors, Org.Commun. 6, 55-67.

[16] A. Akıncioğlu, M. Topal, İ. Gülçin and S. Göksu (2014). Novel sulfamides and sulfonamides incorporating tetralin scaffold as carbonic anhydrase and acetylcholine esterase inhibitors, Arch. Pharm. 347, 68-76.

[17] M.A..Naveed, N.Riaz, M.Saleem, S.Mussadiq, B.Jabeen, M.Ashraf, A.Shaukat, M.M. Ahmed and A. Jabbar (2016). New enzyme inhibitory constituents from Tribulus longipetalus, Rec.Nat.Prod. 10, 128-136.

[18] L. Polat Köse, I. Gülçin, A.C. Gören, J. Namiesnik, A.L. Martinez-Ayala and S. Gorinstein (2015). LCMS/MS analysis, antioxidant and anticholinergic properties of galanga (Alpinia officinarum Hance) rhizomes, Ind. Crops Prod. 74, 712-721.

[19] M. Topal, H. Gocer, F. Topal, P. Kalin, L. Polat Köse, İ. Gülçin, K.C. Çakmak, M. Küçük, L. Durmaz, A.C. Gören and S.H. Alwasel (2016). Antioxidant, antiradical and anticholinergic properties of cynarin purified from the illyrian thistle (Onopordum illyricum L.), J. Enzyme Inhib. Med. Chem. 31, 266-275.

[20] H. Gocer, F. Topal, M. Topal, M. Küçük, D. Teke, İ. Gülçin, S.H. Alwasel and C.T. Supuran (2016). Acetylcholinesterase and carbonic anhydrase isoenzymes I and II inhibition profiles of taxifolin, J. Enzyme Inhib. Med. Chem. 31, 441-447.

[21] J.A. Verpoorte, S. Mehta and J.T. Edsall (1967). Esterase activities of human carbonic anhydrases B and C, J. Biol. Chem. 242, 4221-4229.

[22] G.L. Ellman, K.D. Courtney, V. Andres and R.M. Featherston (1961). A New and rapid colorimetric determination of acetylcholinesterase activity, Biochem. Pharmacol. 7, 88-95.

[23] P. Taslimi, A. Sujayev, S. Mamedova, P. Kalın, İ. Gulcin, N. Sadeghian, S. Beydemir, Ö.İ. Küfrevioglu, S.H. Alwasel, V. Farzaliyev and S. Mamedov (2017). Synthesis and bioactivity of several new hetaryl sulphonamides, J. Enzyme Inhib. Med. Chem. 32, 137-145.

[24] İ. Gülçin, Ş. Beydemir and M.E. Büyükokuroğlu (2004). In vitro and in vivo effects of dantrolene on carbonic anhydrase enzyme activities, Biol. Pharm. Bull. 27, 613-616.

[25] H.I. Gül, A. Demirtas, G. Ucar, P. Taslimi and İ. Gülçin (2017). Synthesis of Mannich bases by two different methods and evaluation of their acetylcholine esterase and carbonic anhydrase inhibitory activities, Lett. Drug Des. Discov. 14, 573-580.

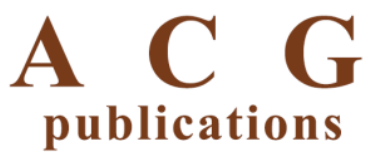

(C) 2017 ACG Publications 